\title{
Healthy reduced-fat Bologna sausages enriched in ALA and DHA and stabilized with Melissa officinalis extract
}

\section{-Short communication-}

Izaskun Berasategi ${ }^{1}$, Íñigo Navarro-Blasco ${ }^{2}$, Maria Isabel Calvo ${ }^{3}$, Rita Yolanda Cavero $^{4}$, Iciar Astiasarán ${ }^{1}$, Diana Ansorena ${ }^{1 *}$

1 Department of Nutrition, Food Science and Physiology, Faculty of Pharmacy, University of Navarra, Irunlarrea s/n, 31008-Pamplona, Spain.

2 Department of Chemistry and Soil Science, Faculty of Sciences, University of Navarra. Irunlarrea s/n, 31008-Pamplona, Spain.

3 Department of Pharmacy and Pharmaceutical Technology, Faculty of Pharmacy, University of Navarra, Irunlarrea s/n, 31008-Pamplona, Spain.

${ }^{4}$ Department of Plant Biology (Botany), Faculty of Sciences, University of Navarra, Irunlarrea s/n, 31008-Pamplona, Spain.

*Corresponding author: Tel.: +34 948425600 (ext. 6263); Fax: +34 948425649.

E-mail address: dansorena@unav.es 


\section{ABSTRACT}

Reduced-energy and reduced-fat Bologna products enriched with $\omega-3$ polyunsaturated fatty acids were formulated by replacing the pork back-fat by an oil-in-water emulsion containing a mixture of linseed-algae oil stabilized with a lyophilized Melissa officinalis extract. Healthier composition and lipid profile was obtained: $85 \mathrm{kcal} / 100 \mathrm{~g}, 3.6 \%$ fat, $0.6 \mathrm{~g}$ ALA and $0.44 \mathrm{~g}$ DHA per $100 \mathrm{~g}$ of product and $\omega-6 / \omega-3$ ratio of 0.4 . Technological and sensory problems were not detected in the new formulations. Besides, reformulation did not cause oxidation problems during 32 days of storage under refrigeration. The results suggest that it is possible to obtain reduced-fat Bolognatype sausages rich in ALA and DHA and stabilized with natural antioxidants, applying the appropriate technology without significant effects over the sensory quality, obtaining interesting products from a nutritional point of view.

\section{Highlights}

- Nutrition claims for Bologna-type meat products.

- Sensory viability of healthier cooked reduced-fat meat products.

- Natural antioxidants to preserve omega-3 enriched meat products.

Key words: algae oil, DHA, reduced-fat, functional foods, cooked sausages, Melissa officinalis 


\section{INTRODUCTION}

Among the vegetable oils with a high content of $\alpha$-linolenic acid (ALA), which are those obtained from linseed (Linum usitatissimum L.), chia (Salvia hispanica L.) and perilla (Perilla frutescens) seeds, linseed oil has been the most frequently used to improve the lipid profile of different foods. According to the Dietary Guidelines for Americans (2010), plant sources of $\omega-3$ fatty acids cannot be considered as replacers for seafood-derived $\omega-3$ polyunsaturated fatty acids (PUFAs), which are rich in docosahexaenoic acid (DHA) and eicosapentaenoic acid (EPA), long chain $\omega-3$ PUFAs. Health-related associations have established specific recommendations for DHA and EPA. Current recommendation from the American Heart Association includes consumption of DHA and EPA fatty acids of $1 \mathrm{~g} /$ day to reduce risk of cardiovascular diseases (Kris-Etherton et al., 2012). Meanwhile, the European Food Safety Authority (EFSA) set Dietary Reference Values (DRV) of $250 \mathrm{mg}$ for EPA plus DHA for adults (EFSA, 2009).

Algae oil has been described as one of the best natural sources of DHA, reaching in certain types of microalgae and obtaining conditions values up to $45 \%$ of total fatty acids (Anderson \& Ma, 2009; Astiasarán \& Ansorena, 2009; Mozaffarian \& Wu, 2011). The use of algae oil from the micro-algaes Ulkenia sp. and Schizochytrium sp. as novel food ingredient was recently regulated (European Commission, 2009a,b). Different works have successfully studied the incorporation of algae oil in different products, such as eggs (Sedoski et al., 2012), surimi (Pietrowski et al., 2011), dry fermentedsausages (García-Íñiguez de Ciriano et al., 2010), yoghourt or milk (Chee et al., 2005).

On the other hand, lipids are the bioactive components that have received most attention in the development of healthier meat products (Delgado-Pando et al., 2010a,b, 2011). 
Decreasing the amount of fat or changing the characteristics of the lipid fraction have been commonly attempted. However, the production of reduced-fat meat products may cause technological problems due to the fact that fat affects flavour, palatability and texture of foods (Hort et al., 2007; Delgado-Pando et al., 2010a,b; Horita et al., 2011). In order to solve this problem, different fat replacers have been tested, being carrageenan the one who provided good results for maintaining textural properties in different meat products (Candogan \& Kolsarici, 2003; Kumar \& Sharma, 2004; Cierach et al., 2009; Ayadi et al., 2009). In fact, previous papers pointed out that it is possible to develop Bologna-type sausages with very low amount of pork back-fat using different emulsifiers (Sanjeewa et al., 2010; Omana et al., 2012).

The lipid profile of cooked meat products can be modified by reformulation strategies (Trindade et al., 2011; Jiménez-Colmenero et al., 2012), including linseed oil, rich in $\alpha$ linolenic acid (Berasategi et al., 2011; Delgado-Pando et al., 2012a,b) in the formulations. However, to our knowledge, there are no studies where this enrichment is carried out with DHA and/or EPA.

In addition, the increase in long chain unsaturated fatty acids could increase lipid oxidation, which might cause sensory problems. Previous papers have demonstrated that it is possible to develop new stable high fat meat products rich in $\omega-3$ PUFA adding synthetic antioxidants such as butylhydroxyanisol (BHA) (Lee et al., 2006; Valencia et al., 2006a,b, 2007). However, public attitude towards these substances is not as positive as that for natural ones, which are very well appreciated (Johnston et al., 2005; GarcíaÍñiguez de Ciriano et al., 2009). In this sense, different methanolic, ethanolic and water extracts obtained from Melissa officinalis have shown antioxidant properties in vitro (Zandi \& Ahmandi, 2000; López et al., 2007), mainly due to the presence of flavonoids and hydroxycinnamic acid derivates, known by their antioxidant capacity, with 
rosmarinic acid the major component (Dastmalchi et al., 2008). Some of these extracts efficiently controlled lipid oxidation in meat products with high fat content (GarcíaÍñiguez de Ciriano et al., 2010; Berasategi et al., 2011).

The objective of this study was to assess the effectiveness of a natural antioxidant (lyophilized extract of Melissa officinalis) as compared to a synthetic one (BHA) in reduced-fat Bologna formulations enriched in ALA and DHA.

\section{MATERIAL AND METHODS}

\subsection{Materials}

Pork shoulder-meat and back fat were obtained from a local meat market. Linseed oil (Biolasi Productos Naturales, Guipúzcoa, Spain) was obtained in a local market and algae oil (DHASCO ${ }^{\circledR}-\mathrm{S}$ ) was purchased to Martek Bioscience Corporation (Columbia, USA). BDRom Carne (a mixture of typical aromatic compounds) and the red colorant Carmin de Cochenille 50\% (E-120) were obtained from BDF Natural Ingredients S.L. (Girona, Spain). Satiagel (gelling refined mixture of kappa and iota carrageenan) was donated by Cargill S.L.U. (Martorell, Barcelona, Spain). Curavi (a mixture of curing agents: sodium chloride, sodium nitrite (E-250), sodium nitrate (E-252) and sodium citrate (E-331) and the rest of additives and spices used in the formulations were kindly donated by ANVISA (Arganda del Rey, Madrid, Spain). All the chemical reagents were obtained from Sigma-Aldrich Chemical Co. (MO, USA).

\subsection{Sausage formulation and processing}

Three different formulations of reduced-fat (RF) Bologna-type sausages were manufactured in a pilot plant (Table 1). Five \% pork back-fat was the only lipid source 
in low-fat control products (LF-Control) whereas the two modified batches substituted the pork back-fat by an oil-in-water $(\mathrm{O} / \mathrm{W})$ emulsion rich in $\omega-3$ fatty acids. The emulsion was prepared according to the procedure described by García-Íniguez de Ciriano et al. (2010), using a mixture of linseed and algae oils (1:1). RF-control type was produced without the addition of extra antioxidants. According to previous experiments (Berasategi et al., 2011), addition of extra antioxidants is needed when cooked meat products are elaborated with high PUFA fat sources. So, RF-BHA type added 200 ppm of BHA, and RF-melisa type added 200 ppm of Melissa officinalis lyophilized aqueous extract.

All ingredients (including the emulsion, when used) were thoroughly minced in a chilled cutter for 1 minute at low speed, and for 2 minutes at high speed until a complete emulsification of the mixture was obtained. After the application of a vacuum process to exclude oxygen from the mixture ( 2 minutes), the batters were stuffed in 6 cm diameter water impermeable plastic casings. Sausages were cooked in a water bath at $80{ }^{\circ} \mathrm{C}$ for $1 \mathrm{~h}$, until the core of the product reached $72{ }^{\circ} \mathrm{C}$. Once heating was completed, the sausages were immediately cooled in a water bath for $2 \mathrm{~h}$ and stored under refrigeration $\left(4^{\circ} \mathrm{C}\right)$ until analysis. The experiment was carried out in triplicate.

\subsection{Melissa officinalis aqueous extract}

\subsubsection{Preparation of the extract}

A lyophilized hydro-alcoholic extract of Melissa officinalis was prepared according to the procedure described by Berasategi et al. (2011). A purification of this extract was done for increasing its antioxidant capacity. Thus, the lyophilized hydro-alcoholic extract was washed with ethanol three times and the solid residue was redissolved in water. The aqueous extract was lyophilized with a freeze-dryer cryodo (Telstar, 
Barcelona, Spain), previous freezing at $-80^{\circ} \mathrm{C}$ in a MDF-V5386S Ultra-LowTemperature Freezer (Sanyo Electric Co., Ltd., Japan). The antioxidant capacity of the aqueous extract was evaluated using DPPH and ORAC methods.

\subsubsection{Characterization of antioxidant capacity}

\subsubsection{2,2-diphenyl-1-picrylhydrazyl (DPPH) method}

The DPPH assay was performed according to García-Íñiguez de Ciriano et al. (2010). Results were expressed as mg Trolox/g lyophilized extract of Melissa officinalis. Absorbance measurements were done in duplicate for each dilution of lyophilized extract.

\subsubsection{Oxygen Radical Absorbance Capacity $\left(\mathrm{ORAC} \mathrm{FL}_{\mathrm{FL}}\right)$ Assay}

$\mathrm{ORAC}_{\mathrm{FL}}$ assays were performed similarly to those described by $\mathrm{Ou}$ et al. (2001). Melissa officinalis lyophilized ( $5 \mathrm{~g}$ ) water extract were dissolved in $50 \mathrm{~mL}$ of phosphate buffer $10 \mathrm{mM}$. A $0.5 \mathrm{M}$ stock solution of Trolox was prepared in $10 \mathrm{mM}$ phosphate buffer, and divided into $1 \mathrm{~mL}$ aliquots, which were stored at $-20^{\circ} \mathrm{C}$ until use. A new set stock Trolox vials were taken from the freezer daily for the preparation of the calibration curve and the quality controls $(12.5$ and $50 \mu \mathrm{M})$. The phosphate buffer solution was used as blank, to dissolve the Trolox quality controls and to prepare the samples. To conduct the ORAC assay, $40 \mu \mathrm{L}$ of the sample and $120 \mu \mathrm{L}$ of the fluorescein solution $(132.5 \mathrm{nM})$ were added to the 96 well black plate. The microplate was equilibrated $\left(5 \mathrm{~min}, 37^{\circ} \mathrm{C}\right)$ then the reaction was initiated by the addition of AAPH (40 $\mu \mathrm{L}, 300 \mathrm{mM}$ ); readings were obtained immediately, in a FLUOStar Omega spectrofluorometric analyzer (BMG Labtechnologies, Offenburg, Germany). The antioxidant capacity was expressed as mols Trolox equivalent/g lyophilized extract. 


\subsection{Storage in refrigeration}

All products were stored under refrigeration $\left(4^{\circ} \mathrm{C}\right)$ during 32 days. Fat extraction and measurement of TBARs was made after 1, 6, 12, 18 and 32 days of storage.

\subsection{Chemical analysis}

The water activity $\left(\mathrm{a}_{\mathrm{w}}\right)$ was determined using a Novasina aw-Center, (Novasina AG., Lanchen; Switzerland). Total fat was determined by Soxhlet (Extraction System B-811, Büchi Labortechnik AG, Flawil, Switzerland) extraction with petroleum ether (AOAC, 2002a). AOAC $(2002 b, c)$ official methods were used for moisture and protein determination. The method of Folch et al. (1957) was used for the extraction of fat, previous addition of BHT to prevent lipid oxidation during extraction. The fatty acid profile was determined in the lipid extract by gas chromatography-FID (Clarus 500, Perkin Elmer, Waltham, Massachusetts, USA), previous derivatization to form the fatty acid methyl esters, as described by Valencia et al. (2008).

\section{TBARs (Thiobarbituric acid value)}

TBARs values were determined on fat basis according to the method described by Berasategi et al. (2011).

\subsection{Texture}

A Universal texture analyzer (TA-XT2i, Stable Micro Systems, Surrey, United Kingdom) was used to conduct the texture profile analysis (TPA) (Bourne, 1978). Slices of sausage $(6 \mathrm{~cm}$ diameter and $1 \mathrm{~cm}$ thickness) were compressed to $60 \%$ of their original height with a compression plate of $75 \mathrm{~mm}$ diameter. Force-time curves were recorded at a crosshead speed of $5 \mathrm{~mm} / \mathrm{s}$. Hardness (g), Springiness (mm), Cohesiveness, Gumminess $(\mathrm{g})$ and Chewiness $(\mathrm{g} / \mathrm{mm})$ were evaluated using the 
available computer software. Measurements were done in twelve different samples per type of product.

\subsection{Colour}

For colour measurement, slices of sausage $(6 \mathrm{~cm}$ diameter and $1 \mathrm{~cm}$ thickness $)$ were covered with a polyethylene film, with pressure to obtain a uniform, bubble-free surface. A digital colorimeter (Chromameter-2 CR-200, Minolta, Osaka, Japan) was used to obtain the reflectance spectra. Colour coordinates were obtained with the conditions established by Ansorena et al. (1997) (CIE L* a* $b^{*}$ system, angle $10^{\circ}$, illuminant D65). $\mathrm{L}^{*}, \mathrm{a}^{*}$ and $\mathrm{b}^{*}$ parameters indicate lightness, redness and yellowness, respectively. Chroma angle, Hue angle and Colour difference $\left(\Delta \mathrm{E}^{*}\right)$ were calculated as follows:

$$
\begin{gathered}
\text { Hue }=\operatorname{arctg}\left(\frac{b^{*}}{a^{*}}\right) \quad \text { Chroma }=\sqrt{a^{*^{2}+b^{* 2}}} \\
\Delta E^{*}=\sqrt{\left(\Delta L^{*}\right)^{2}+\left(\Delta a^{*}\right)^{2}+\left(\Delta b^{*}\right)^{2}}
\end{gathered}
$$

Measurements were done in four different samples per type of product.

\subsection{Cooking yield (\%)}

The cooking yield was calculated as follows: (weight of sausage before cook - weight loss) / weight of sausage before cook * 100 .

\subsection{Sensory analysis}

A triangular test was performed to determine the existence of perceptible sensory differences in colour, hardness, taste and appearance among the three types of sausages. A total of 17 semi-trained panellists participated in the sessions. Each panellist was presented with three samples, of which two were identical, and asked to indicate which 
sample differed from the others. The number of correct answers was determined and data shown in the table corresponded to the mean value obtained for each type of product by the 17 panellists. According to the Spanish norm UNE 87-006-92 (1992), for a 17 members panel, the difference among samples was significant if the number of correct answers were $10(* \mathrm{p}<0.05), 11(* * \mathrm{p}<0.01)$ and $13(* * * \mathrm{p}<0.001)$. ns: not significant.

\subsection{Statistical analysis}

Mean and standard deviation of data are shown in all tables. A one way Anova test and the Tukey- $b$ posteriori test were used to determine significant differences among the different types of Bologna-type sausages and among different times of storage. SPSS version 15.0 was used (SPSS inc. Chicago, Illinois, USA). Significance level of $p \leq 0.05$ was used for all evaluations.

\section{RESULTS AND DISCUSSION}

The fat and energy content of the different types of products were shown in Table 2. Modified products showed $1 \%$ less fat than RF-control due to the higher water content of the emulsion $(42.1 \%)$ compared to that of the pork back-fat $(20.6 \%)$ that made modified products to increase moisture ( $79.4 \mathrm{~g} / 100 \mathrm{~g}$ product) compared to control ones (77.9 g/100 g product). The three types of products showed energy values lower than $100 \mathrm{kcal} / 100 \mathrm{~g}$ product, but modified ones, due to their lower fat content, showed even

a $10 \%$ less kcal content. Comparing this energy value with that of traditional formulations for this type of products (around $300 \mathrm{kcal} / 100 \mathrm{~g}$ ), the energy decrease was higher than $30 \%$. In consequence, the three proposed formulations presented in this paper could be claimed as "light" or "energy-reduced" according to the current 
European Regulation on nutrition claims (UE Regulation (CE), No 116/2010). The amount of protein of these products was similar to that of traditional ones $(14 \mathrm{~g} / 100 \mathrm{~g})$, so there was no lack of protein supply of these products compared to those with high energy value.

Only the main fatty acids summatories and relevant ratios from the nutritional standpoint were presented from the complete fatty acid profile (Table 2). An effective modification of these parameters was induced by the use of the emulsion. RF products elaborated with pork back fat showed a typical PUFA/SFA (0.5), PUFA+MUFA/SFA (1.8) and $\omega-6 / \omega-3$ (17) ratios for meat products. However, RF products formulated with the linseed:algae $\mathrm{O} / \mathrm{W}$ emulsion inverted the PUFA/SFA ratio $(\approx 1.6)$, almost duplicated the PUFA+MUFA/SFA ratio $(\approx 3)$ and significantly decreased the $\omega-6 / \omega-3$ ratio $(\approx 0.4)$. Moreover, these last products supplied significant amounts of ALA $(0.60 \mathrm{~g} / 100 \mathrm{~g}$ product) and DHA $(0.44 \mathrm{~g} / 100 \mathrm{~g}$ product $)$, which were not present in the control products. It has to be noted that these values were similar to the limit established by the Commission Regulation for the claim "high $\omega-3$ ", which is $0.6 \mathrm{~g} \alpha$-linolenic per $100 \mathrm{~g}$ and $100 \mathrm{kcal}$, confirming the nutritional benefit achieved with these formulations. In addition, regarding the long chain $\omega-3$ fatty acids, one portion of modified product (50 g) contributed with $88 \%$ of the recommendation of EFSA (2009).

Furthermore, the total amounts of SFA and trans were 1.09 and $1.15 \mathrm{~g} \mathrm{SFA}+\operatorname{trans} / 100 \mathrm{~g}$ product, that were below the upper limit established by UE Regulation for the claim "low saturated fat".

Regarding the technological parameters, $\mathrm{a}_{\mathrm{w}}$ and weight loss values were similar to those obtained in traditional products, without differences among the three types of formulations (Table 3). The use of impermeable casings allowed, as expected, maintaining a high cooking yield value, as reported by other authors in similar products 
(Cáceres et al., 2008). In relation to the TPA results, there were not relevant differences among the different types of products. In the case of RF-BHA type, hardness and chewiness were statistically lower than in other types, but according to the sensory analysis, that was not a critical factor for the quality of the products. As is it widely known, animal fat is very important for conferring food texture properties. Hence, carrageenan was used as fat replacer to avoid textural problems. All these formulations contained $10 \mathrm{~g} / \mathrm{kg}$ of carrageenan, which was obviously determinant for maintainig the water holding capacity, but also for making possible to incorporate high amounts of emulsion without noticing texture defects. In addition to studies in which carrageenan gave good sensory results in low-fat cooked products regarding their contribution to the texture (Candogan \& Kolsarici, 2003; Cierach et al., 2009), our work demonstrated their effectiveness in pork back-fat-free formulas, where the lipid source (oils) were incorporate as an oil-in-water emulsion.

When instrumental colour data were analysed (Table 3), lightness, yellowness and consequently, chroma, increased significantly in reduced-fat products with emulsion. yellowness and chroma were higher in RF-melisa type products, but $\Delta \mathrm{E}^{*}$ between RFBHA and RF-melisa type was very low (0.74), being visually imperceptible colour difference $(<2)$ (Francis \& Clydesdale, 1975). Redness was similar in the three types of formulations.

Other works found similar effect over colour with substitutions of animal fat with vegetable oils in different meat products (Bishop et al., 1993; Park et al., 2005; Jiménez-Colmenero et al., 2010; Youssef \& Barbut, 2011). The last authors concluded that this fact can be probably related to the much smaller oil globules diameter, which reflect more light than the larger animal fat globules. Other authors (Márquez et al., 
1989; Paneras \& Bloukas, 1994; Delgado-Pando et al., 2010a,b) did not detect changes in colour parameters in formulations with vegetable oils.

Triangular sensory analysis aimed reporting potential differences between the reducedfat formulation and that enriched in $\omega-3$ and protected with a well-known antioxidant (BHA). Also the use of the two antioxidants in $\omega-3$ enriched products was compared. Results showed that only in odour significant differences were reported between RFcontrol and RF-BHA types, being statistically similar in other parameters. Similar characteristics were reported for both $\omega-3$ enriched products, as no statistical differences were found for odour, taste, juiciness and texture. Thus, the use of melisa did not cause any differential note from the sensory point of view.

In Figure 1 the evolution of TBARs along the time of storage in the three types of products can be observed. Within each type of product, although there were small changes during the first days of storage time, no significant changes were found between day 0 and day 32 of analysis. Also, TBARs values for RF-control product maintained consistently lower TBARs values than modified ones. In any case, despite the highly unsaturation degree of the modified formulations, they maintained low TBARs values $(<0.5 \mathrm{mg}$ malondialdehyde/kg product), comparable to those obtained in conventional cooked meat products. García-Íñiguez de Ciriano et al. (2010) evaluated firstly oxidation of linseed:algae oil emulsions stabilized with Melissa officinalis extract, observing positive results. Then, they substituted $25 \%$ of pork back-fat of dryfermented sausages by a similar emulsion demonstrating also its efficacy in this system. Additionally, Berasategi et al. (2011) observed similar results in high-fat Bologna-type sausages with pork back-fat and linseed oil-in-water emulsion stabilized with the same extract. With the results obtained in this work it can be concluded that the susceptibility to oxidation of products with a highly unsaturated oil emulsion as the only lipid source 
in reduced-fat products was guaranteed by the addition of antioxidants, including a natural antioxidant water extract from melisa.

In conclusion, the use of Melissa officinalis as natural antioxidant was effective to prevent lipid oxidation of new formulations of reduced-fat Bologna type sausages. These new products, technologically and sensory viable, were pork back-fat free and enriched in ALA and DHA due to the use of preemulsified linseed and algae oil in the formulation.

\section{ACKNOWLEDGEMENTS}

We thank the "Programa Consolider-Ingenio 2010 CARNISENUSA CSD2007-00016" and the "Proyecto AGL2008-01099/ALI" (Ministerio de Ciencia e Innovación), for their contribution to the financial support of this work. I. Berasategi is grateful to "Asociación de Amigos de la Universidad de Navarra" for the grants received. We are also grateful to Dr. Mohino (ANVISA) and to Cargill S.L.U. for the supply of Satiagel. Andrea Echarte Ayerra is acknowledged for her help during the analysis.

\section{REFERENCES}

Anderson, B., \& Ma, D. W. L. (2009). Are all n-3 polyunsaturated fatty acids created equal? Lipids in Health and Disease, 8, 33.

Ansorena, D., DePena, M. P., Astiasarán, I., \& Bello, J. (1997). Colour evaluation of chorizo de Pamplona, a Spanish dry fermented sausage: Comparison between the CIE L*a*b* and the hunter lab systems with illuminants D65 and C. Meat Science, 46(4), 313-318.

AOAC. (2002a). Fat (crude) or ether extract in meat. 960.39. In W. Horwitz (Ed.), Official method of analysis. (17th ed., pp. 12-13). Gaithersburg, Maryland: Association of Official Analytical Chemists. 
AOAC. (2002b). Determination of moisture content. 950.46. In W. Horwitz (Ed.), Official method of analysis. (17th ed., pp. 12-13). Gaithersburg, Maryland: Association of Official Analytical Chemists.

AOAC. (2002c). Crude protein in meat. 981.10. In W. Horwitz (Ed.), Official method of analysis. (17th ed., pp. 7-8). Gaithersburg, Maryland: Association of Official Analytical Chemists.

Astiasarán, I., \& Ansorena, D. (2009). Algal oil. In R. A. Moreau, \& A. Kamal-Eldin (Eds.), Gourmet and health-promoting specialty oils (pp. 491-513). Urbana. Illinois. USA: AOACS Press.

Ayadi, M. A., Kechaou, A., Makni, I., \& Attia, H. (2009). Influence of carrageenan addition on turkey meat sausages properties. Journal of Food Engineering, 93(3), $278-283$

Berasategi, I., Legarra, S., García-Íniguez de Ciriano, M., Rehecho, S., Calvo, M. I., Cavero, R. Y., et al. (2011). 'High in omega-3 fatty acids' bologna-type sausages stabilized with an aqueous-ethanol extract of Melissa officinalis. Meat Science: 88(4), 705-711.

Bishop, D. J., Olson, D. G., \& Knipe, C. L. (1993). Pre-emulsified corn-oil, pork fat, or added moisture affect quality of reduced fat bologna quality. Journal of Food Science, 58(3), 484-487.

Bourne, M. C. (1978). Texture profile analysis. Food Technology, 32(7), 62-66.

Cáceres, E., García, M. L., \& Selgas, M. D. (2008). Effect of pre-emulsified fish oil - as source of PUFA $n-3$ - on microstructure and sensory properties of mortadella, a Spanish bologna-type sausage. Meat Science, 80(2), 183-193.

Candogan, K., \& Kolsarici, N. (2003). The effects of carrageenan and pectin on some quality characteristics of low-fat beef frankfurters. Meat Science, 64(2), 199-206. 
Chee, C. P., Gallaher, J. J., Djordjevic, D., Faraji, H., McClements, D. J., Decker, E. A., et al. (2005). Chemical and sensory analysis of strawberry flavoured yogurt supplemented with an algae oil emulsion. Journal of Dairy Research, 72(3), 311316.

Cierach, M., Modzelewska-Kapitula, M., \& Szacilo, K. (2009). The influence of carrageenan on the properties of low-fat frankfurters. Meat Science, 82(3), 295299.

Dastmalchi, K., Dorman, H., Oinonen, P., Darwis, Y., Laakso, I., \& Hiltunen, R. (2008). Chemical composition and in vitro antioxidative activity of a lemon balm (Melissa officinalis L.) extract. Food Science Technology, 41(3), 391-400.

Delgado-Pando, G., Cofrades, S., Ruiz-Capillas, C., \& Jiménez-Colmenero, F. (2010a). Healthier lipid combination as functional ingredient influencing sensory and technological properties of low-fat frankfurters. European Journal of Lipid Science and Technology, 112(8), 859-870.

Delgado-Pando, G., Cofrades, S., Ruiz-Capillas, C., Teresa Solas, M., \& JiménezColmenero, F. (2010b). Healthier lipid combination oil-in-water emulsions prepared with various protein systems: An approach for development of functional meat products. European Journal of Lipid Science and Technology, 112(7), 791801.

Delgado-Pando, G., Cofrades, S., Ruiz-Capillas, C., Teresa Solas, M., Triki, M., \& Jiménez-Colmenero, F. (2011). Low-fat frankfurters formulated with a healthier lipid combination as functional ingredient: Microstructure, lipid oxidation, nitrite content, microbiological changes and biogenic amine formation. Meat Science, 89(1), 65-71. 
Delgado-Pando, G., Cofrades, S., Ruiz-Capillas, C., Triki, M., \& Jimenez-Colmenero, F. (2012a). Enriched n-3 PUFA/konjac gel low-fat pork liver pate: Lipid oxidation, microbiological properties and biogenic amine formation during chilling storage. Meat Science, 92(4), 762-767.

Delgado-Pando, G., Cofrades, S., Ruiz-Capillas, C., Triki, M., \& Jimenez-Colmenero, F. (2012b). Low-fat pork liver pates enriched with n-3 PUFA/konjac gel: Dynamic rheological properties and technological behaviour during chill storage. Meat Science, 92(1), 44-52.

EFSA. (2009). Scientific opinion of the panel on dietetic products, nutrition and allergies on a request from the commission related to labelling reference intake values for n-3 and n-6 polyunsaturated fatty acids. The EFSA Journal, 1176, 1-11.

European Commision. (2009a). Commission decision of 21 October 2009 concerning the extension of uses of algal oil from the micro-algae Ulkenia sp. as a novel food ingredient under Regulation (EC) No 258/97 of the European Parliament and of the Council.

European Commision. (2009b). Commision decision of 22 October 2009 concerning the extension of uses of algal oil from the micro-algae Schizochytrium sp. as a novel food ingredient under Regulation (EC) No 258/97 of the European Parliament and of the Council.

European Commission. (2010). Regulation (CE) No 116/2010 amending Regulation (EC) No 1924/2006 of the European Parliament and of the Council of 9 February 2010 with regard to the list of nutrition claims. Official Journal of the European Union, L 37, 16-18.

Francis, F.J., \& Clydesdale, F.M. (1975). Food colorimetry: theory and application. New York, USA: Chapman \& Hall. 
Folch, J., Lees, M., \& Stanley, G. H. S. (1957). A simple method for the isolation and purification of total lipids from animal tissues. Journal of Biological Chemistry, 226(1), 497-509.

García-Íñiguez de Ciriano, M., García-Herreros, C., Larequi, E., Valencia, I., Ansorena, D., \& Astiasarán, I. (2009). Use of natural antioxidants from lyophilized water extracts of Borago officinalis in dry fermented sausages enriched in $\omega-3$ PUFA. Meat Science, 83(2), 271-277.

García-Íñiguez de Ciriano, M., Rehecho, S., Calvo, M. I., Cavero, R. Y., NavarroBlasco, Í., Astiasarán, I., \& Ansorena, D. (2010). Effect of lyophilized water extracts of Melissa officinalis on the stability of algae and linseed oil-in-water emulsion to be used as a functional ingredient in meat products. Meat Science, 85(2), 373-377.

Horita, C. N., Morgano, M. A., Celeghini, R. M. S., \& Pollonio, M. A. R. (2011). Physico-chemical and sensory properties of reduced-fat mortadella prepared with blends of calcium, magnesium and potassium chloride as partial substitutes for sodium chloride. Meat Science, 89(4), 426-433.

Hort, J.E. \& Cook, D. (2007). Formulating low-fat food: The challenge of retaining flavour quality. In Taylor, A. \& Hort, J., Modifying flavour in food (pp. 131-143). Cambridge, England: Woodhead Publishing in Food Science, Technology and Nutrition.

Jiménez-Colmenero, F., Herrero, A., Pintado, T., Solas, M. T., \& Ruiz-Capillas, C. (2010). Influence of emulsified olive oil stabilizing system used for pork backfat replacement in frankfurters. Food Research International, 43(8), 2068-2076. 
Jiménez-Colmenero, F., Cofrades, S., Herrero, A. M., Fernández-Martín, F., RodríguezSalas, L., \& Ruiz-Capillas, C. (2012). Konjac gel fat analogue for use in meat products: Comparison with pork fats. Food Hydrocolloids, 26(1), 63-72.

Johnston, J. E., Sepe, H. A., Miano, C. L., Brannan, R. G., \& Alderton, A. L. (2005). Honey inhibits lipid oxidation in ready-to-eat ground beef patties. Meat Science, $70(4), 627-631$.

Kris Etherton, P., Lefevre, M., Mensink, R., Petersen, B., Fleming, J., \& Flickinger, B. (2012). Trans fatty acid intakes and food sources in the U.S. population: NHANES 1999-2002. Lipids, 47(10), 931-40.

Kumar, M., \& Sharma, B. D. (2004). The storage stability and textural, physicochemical and sensory quality of low-fat ground pork patties with carrageenan as fat replacer. International Journal of Food Science and Technology, 39(1), 31-42.

Lee, S., Faustman, C., Djordjevic, D., Faraji, H., \& Decker, E. (2006). Effect of antioxidants on stabilization of meat products fortified with n-3 fatty acids. Meat Science, 72(1), 18-24.

Lopez, V., Akerreta, S., Casanova, E., Garcia-Mina, J., Cavero, R., \& Calvo, M. (2007). In vitro antioxidant and anti-rhizopus activities of lamiaceae herbal extracts. Plant Foods for Human Nutrition, 62(4), 151-155.

Márquez, E. J., Ahmed, E. M., West, R. L., \& Johnson, D. D. (1989). Emulsion stability and sensory quality of beef frankfurters produced at different fat or peanut oil levels. Journal of Food Science, 54(4), 867-870.

Mozaffarian, D., \& Wu, J. H. Y. (2011). Omega-3 fatty acids and cardiovascular disease effects on risk factors, molecular pathways, and clinical events. Journal of the American College of Cardiology, 58(20), 2047-2067. 
Omana, D. A., Pietrasik, Z., \& Betti, M. (2012). Use of poultry protein isolate as a food ingredient: Sensory and color characteristics of low-fat turkey bologna. Journal of Food Science, 77(7), S274-S280.

Ou, B. X., Hampsch-Woodill, M., \& Prior, R. L. (2001). Development and validation of an improved oxygen radical absorbance capacity assay using fluorescein as the fluorescent probe. Journal of Agricultural and Food Chemistry, 49(10), 4619-4626.

Paneras, E. D., \& Bloukas, J. G. (1994). Vegetable-oils replace pork backfat for low-fat frankfurters. Journal of Food Science, 59(4), 725-728.

Park, J. C., Jeong, J. Y., Lee, E. S., Choi, J. H., Choi, Y. S., Yu, L. H., et al. (2005). Effects of replaced plant oils on the quality properties in low fat hamburger patties. Korean Journal of Food Science and Technology, 37(3), 412-417.

Pietrowski, B. N., Tahergorabi, R., Matak, K. E., Tou, J. C., \& Jaczynski, J. (2011). Chemical properties of surimi seafood nutrified with omega-3 rich oils. Food Chemistry, 129(3), 912-919.

Sanjeewa, W. G. T., Wanasundara, J. P. D., Pietrasik, Z., \& Shand, P. J. (2010). Characterization of chickpea (Cicer arietinum L.) flours and application in low-fat pork bologna as a model system. Food Research International, 43(2), 617-626.

Sedoski, H. D., Beamer, S. K., Jaczynski, J., Partington, S., \& Matak, K. E. (2012). Sensory evaluation and quality indicators of nutritionally-enhanced egg product with omega-3 rich oils. LWT-Food Science and Technology, 47(2), 459-464.

Trindade, M. A., De Oliveira, J. M., Nogueira, N. M. G., Oliveira Filho, P. R. C., De Alencar, S. M., \& Contreras-Castilo, C. J. (2011). Mortadella sausage produced with soybean oil instead of pork fat. Italian Journal of Food Science, 23(1), 72-79.

UNE 87-006-92. (1992). Norma Española. Metodología Prueba Triangular. 
U.S. Department of Agriculture and U.S. Department of Health and Human Services. Dietary Guidelines for Americans. (2010). $7^{\text {th }}$ edition. Washington, DC: U.S. Government Printing Office.

Valencia, I., Ansorena, D., \& Astiasarán, I. (2006a). Nutritional and sensory properties of dry fermented sausages enriched with $n-3$ PUFAs. Meat Science, 72(4), 727733.

Valencia, I., Ansorena, D., \& Astiasarán, I. (2006b). Stability of linseed oil and antioxidants containing dry fermented sausages: A study of the lipid fraction during different storage conditions. Meat Science, 73(2), 269-277.

Valencia, I., Ansorena, D., \& Astiasarán, I. (2007). Development of dry fermented sausages rich in docosahexaenoic acid with oil from the microalgae Schizochytrium sp.: Influence on nutritional properties, sensorial quality and oxidation stability. Food Chemistry, 104(3), 1087-1096.

Valencia, I., O'Grady, M., Ansorena, D., Astiasaran, I., \& Kerry, J. (2008). Enhancement of the nutritional status and quality of fresh pork sausages following the addition of linseed oil, fish oil and natural antioxidants. Meat Science, 80(4), 1046-1054.

Youssef, M. K., \& Barbut, S. (2011). Fat reduction in comminuted meat productseffects of beef fat, regular and pre-emulsified canola oil. Meat Science, 87(4), 356360.

Zandi, P., \& Ahmadi, L. (2000). Antioxidant effect of plant extracts of Labiatae family. Journal of food science and technology, 37(4), 436-439. 